Chirurgia (2019) 114: 443-450

No. 4, July - August

Copyright@ Celsius

http://dx.doi.org/10.21614/chirurgia.114.4.443

\title{
The Prognostic Role of Pre-operative Positron Emission Tomography-Computed Tomography and Endoscopic Ultrasound Parameters in Oesophageal Adenocarcinoma
}

\author{
Dionysios Dellaportas', Janine Zylstra', James Gossage ${ }^{1,2}$, Cara Baker ${ }^{1,2}$, Mark Kelly ${ }^{1,2}$, Mieke Van Hemelrijck ${ }^{3}$, \\ Nyree Griffin ${ }^{4}$, Jesper Lagergren ${ }^{1,2}$, Andrew R. Davies ${ }^{1,2}$
}

'Department of Surgery, Guy's \& St Thomas' Oesophago-Gastric Centre, London, UK ${ }^{2}$ Section of Gastrointestinal Cancer, Division of Cancer studies, King's College London, UK ${ }^{3}$ Cancer Epidemiology Group, Division of Cancer Studies, King's College London, Kings Health Partners, London, UK ${ }^{4}$ Department of Radiology, Guy's \& St Thomas' NHSFT, London, UK

Corresponding author: Dionysios Dellaportas, MD, PhD FEBS (ECS), Guy's \& St Thomas' Oesophagogastric Centre, London UK, SE1 9EH

E-mail: dellapdio@gmail.com

\section{Abbreviations:}

PET/CT - Positron Emission Tomography/Computed Tomography; EUS - Endoscopic Ultrasound; NAC - neoadjuvant chemotherapy; LN - lymph node;

FDG - fluorodeoxyglucose;

GOJ - gastro-oesophageal junction;

OGD - oesophago-gastro-duodenoscopy; MDT - multidisciplinary team meeting
Received: 07.07 .2019 Accepted: 15.08 .2019

\section{Rezumat}

Rolul prognostic preoperator al investigatiei PET-CT și al ecoendoscopiei în adenocarcinomul esofagului

Context: Evaluarea rolului prognostic al tomografiei cu emisie de pozitroni/computer tomograf (PET-CT) şi al ecoendoscopiei (EUS) efectuate înainte de chimioterapia neoadjuvantă (NAC) şi înainte de intervenția chirurgicală pentru adenocarcinom esofagian (OAC), cu accent pe evaluarea ganglionilor limfatici (LN).

Metode: Pacienti suferind de OAC, tratati într-un centru tertiar în perioada ianuarie 2008 - decembrie 2014 au fost incluşi într-un studiu retrospectiv. Toți pacienții au fost supuşi evaluării cu PETCT şi EUS înainte de NAC şi esofagectomie. Au fost înregistrate informații privind evaluarea PET-CT cu FDG a ganglionilor locali, valoarea SUV a tumorii primare, ganglionii pozitivi şi mărimea tumorii în urma EUS. Au fost efectuate analize univariate şi multivariate, şi studii de supraviețuire.

Rezultate: Studiul a inclus 151 de pacienți care au îndeplinit criteriile de admitere (vârsta medie 62 de ani). Sensibilitatea PETCT şi EUS pentru metastazele ganglionilor limfatici locali a fost de $39,2 \%$ şi $88,6 \%$, cu o specificitate de $83,33 \%$ şi respectiv $19,15 \%$. Nu au existat diferențe de supraviețire globală (OS) între pacienții cu ganglioni limfatici identificați prin PET-CT cu FDG şi cei cu ganglioni limfatici negativi $(\mathrm{p}=0.347)$. Valoarea maximă de absorbtie standardizată (SUVmax) a fost divizată în ridicată şi 
scăzută (valoarea limită medie: 10), neexistând nici o diferență de supraviețuire între grupuri $(p=0.141)$. Mărimea tumorii evidențiată de EUS nu a fost un factor prognostic (OS, $p=0.455)$.

Concluzii: Stadializarea ganglionilor limfatici în adenocarcinomul esofagian nu este precisă. Deşi evaluările PET-CT şi EUS pot fi complementare, nici una din acestea nu poate prezice în mod independent supraviețuirea.

Cuvinte cheie: adenocarcinom esofagian, cancer esofagian, PET-CT, ecoendoscopie

\section{Abstract}

Background: To evaluate the prognostic role of Positron Emission Tomography/Computed Tomography (PET/CT) and Endoscopic Ultrasound (EUS) performed before neoadjuvant chemotherapy (NAC) and surgery for oesophageal adenocarcinoma (OAC) patients, focusing on lymph node (LN) assessment.

Methods: OAC patients treated in a single tertiary center during January 2008 until December 2014 were retrospectively studied. All patients had PET/CT and EUS before NAC and oesophagectomy. PET-FDG-avid local LNs and maximum standardized uptake value (SUVmax) of the primary tumour, EUS positive LNs and EUS tumour length were recorded. Univariate, multivariate and survival analyses were performed.

Results: Following exclusions 151consecutive patients met the inclusion criteria, (median age 62 years). PET/CT and EUS sensitivity for local LNs metastasis was 39.2\% and 88.6\%, with specificities of $83.33 \%$ and $19.15 \%$ respectively. No overall survival (OS) difference was found between patients with PET/CT FDG-avid LNs and those with negative LNs $(p=0.347)$. SUVmax uptake was divided into high and low (median cut-off value: 10 ) with no significant difference in OS between groups $(\mathrm{p}=0.141)$. EUS tumour length was not prognostic (OS, $p=0.455)$.

Conclusions: Initial LN staging in OA is inaccurate. Although PET/CT and EUS assessments may be complimentary, none independently predicted survival.

Key words: oesophageal adenocarcinoma, oesophageal cancer, positron emission tomography, endoscopic ultrasonography

\section{Introduction}

The use of Positron Emission Tomography (PET), especially when combined with Computed Tomography (CT) has significantly improved the initial staging of oesophageal cancer patients, compared with traditional CT scan alone (1). PET/CT has been shown to detect metastatic disease in an additional $10 \%$ of patients who were presumed only to have locoregional disease based on other staging modalities, and changes management overall in $15-20 \%$ of cases (2). Lymph node involvement is an important prognostic indicator and multiple positive lymph nodes are considered a surrogate marker of systemic disease. As a result, most patients undergo neo-adjuvant treatment prior to surgical resection (3). Historically, initial staging modalities, such as PET/CT and Endoscopic Ultrasound (EUS), have shown relatively poor accuracy in lymph node assessment in oesophageal adenocarcinoma patients $(4,5)$.

The aim of this study was to determine the prognostic role of parameters measured by PET/CT and EUS before neoadjuvant chemotherapy and surgery, for oesophageal adenocarcinoma. Specifically, we sought to validate previous studies that demonstrated PET fluorodeoxyglucose (FDG)-avid lymph 
nodes to be prognostic, independent of final tumour stage.

\section{Material and Method}

\section{Patient Inclusion}

This was a retrospective-cohort study taken from a prospectively maintained database of 705 patients, treated by oesophagectomy in a single tertiary center between January 2008 and December 2014. PET imaging was not performed routinely in our unit prior to 2007 and only patients with adenocarcinoma of the oesophagus or gastro-oesophageal junction (GOJ), Siewert Type 1 and 2 were included in the study cohort. Patients with squamous cell carcinoma or other rarer pathologies (sarcoma, GIST, benign lesions) and those without available PET imaging were excluded from the study cohort.

\section{Staging}

After initial diagnosis with oesophago-gastroduodenoscopy (OGD) and biopsy, patients were staged using multidetector CT (chest/abdomen/ pelvis), EUS, FDG-PET/CT and staging laparoscopy, the latter used selectively in patients with tumour extension below the diaphragm. All patients were managed through a dedicated multidisciplinary team meeting (MDT).

PET/CT and EUS were performed the same day as a part of a one-stop service provided for these patients, and endoscopy (two Consultant Gastroenterologists) and radiology (two Radiology-PET/CT Consultants) dedicated teams were blinded apart from the tumour location in their staging assessments.

For the study, specific FDG-PET/CT findings were recorded and analyzed: a. Maximum standardized uptake value (SUV max) of the primary lesion (divided into two groups by a median value of 10) b. FDG-avid local lymph nodes. Local lymph nodes were considered as left gastric, paraoesophageal, subcarinal and aortopulmonary nodes. EUS parameters were also recorded: a. Presence or absence of suspicious lymph nodes, b. Primary tumour length.

Suspicious findings of lymph nodes on PET/CT were enlargement with concurrent necrosis or signs of extracapsular invasion, in the context of elevated SUVmax.

\section{Management}

Following multi-disciplinary team consensus, most patients (T2 or greater and/or having suspicious lymph nodes on imaging) were considered for neo-adjuvant chemotherapy (NAC) followed by tailored surgery. NAC regimens followed established protocols based on randomized controlled trial data $(6,7)$. A combination of Epirubicin, Cisplatin/ Oxaliplatin, and 5-Fluro-uracil/capecitabine (CF, ECF, ECX or EOX) was used in almost all patients (6).

The surgical approach was tailored to the individual patient's tumour characteristics and included Ivor-Lewis, Left thoraco-abdominal and transhiatal oesophagectomy at the individual surgeon's discretion.

\section{Pathological Analysis}

All specimens were examined by one of a dedicated team of upper gastro-intestinal histopathologists at a single centre. The AJCC/TNM 7th Edition was used for all cases. Where histopathology showed malignant cells within $1 \mathrm{~mm}$ of the circumferential resection margin it was considered positive (R1) as per the Royal College of Pathologists criteria (8).

\section{Survival Data}

Survival data were obtained from the unit database, hospital electronic administrative systems, or general practitioner records according to the last confirmed visit to any of the above. The date of surgery was used as the baseline for calculation of survival, and as time of death is defined as time of death from the disease. Recurrent disease was defined as the presence of radiological or histopathological evidence of recurrence as agreed by the MDT. 


\section{Statistical Analysis}

PET/CT suspicious for malignant involvement LNs were compared with final histopathological LN status using descriptive statistics. Univariate and multivariate Cox proportional hazards regression models were then conducted to identify which clinico-demographic characteristics were predictive for disease recurrence or overall death. The model was adjusted for age, tumour stage (I,II,III), Mandard Score (1-2-3,4-5), grade (well, moderately, poorly differentiated), lymphovascular invasion (positive, negative), resection status (R0, R1), PET LNs (positive, negative), SUVmax of the primary $(>10$, $<10$ ), EUS LNs (positive, negative).

Kaplan-Meier survival curves were plotted according to the presence or absence of FDGavid local lymph nodes. Comparisons between groups were made using the log rank test. Two-sided $\mathrm{P}$ values were calculated and $\mathrm{p}<$ 0.05 was considered significant.

\section{Results}

A total of 151 patients were included in the study cohort, (126 male;25 female), with a median age of 62 . Demographics and relevant clinical parameters are presented in Table 1.

FDG-avid local lymph nodes were reported accurately as positive in 38/151 (25.17\%) patients (Table 2), compared to final histopathological examination which revealed 97/151 (64.24\%) of patients had positive lymph nodes. The sensitivity, specificity and accuracy of PET in predicting LNs compared to final pathological analysis was $39.2 \%$, $83.33 \%$ and $54.97 \%$ respectively. The sensitivity of PET/CT at predicting lymph nodes increased
Table 1. Demographics, operative and histopathological data of study sample

\begin{tabular}{|c|c|c|}
\hline & $\begin{array}{c}\text { Number of } \\
\text { patients }\end{array}$ & Percentage \\
\hline $\operatorname{Sex}\left(M / F^{\dagger}\right)$ & $126 / 25$ & $83.44 / 16.56$ \\
\hline Age (median) & 62 & $\mathrm{n} / \mathrm{a}$ \\
\hline \multicolumn{3}{|l|}{ Operative procedure } \\
\hline Left thoracoabdominal oesophagectomy & 63 & 41.72 \\
\hline Ivor-Lewis oesophagectomy & 19 & 12.58 \\
\hline Transhiataloesophagectomy & 69 & 45.7 \\
\hline \multicolumn{3}{|l|}{ Stage } \\
\hline I & 23 & 15.23 \\
\hline ॥ & 44 & 29.14 \\
\hline III & 84 & 55.63 \\
\hline \multicolumn{3}{|l|}{ Lymphovascular invasion } \\
\hline Yes & 100 & 66.23 \\
\hline No & 51 & 33.77 \\
\hline \multicolumn{3}{|l|}{ Grade } \\
\hline I (well diff) & 2 & 1.32 \\
\hline II (moderately diff) & 79 & 52.32 \\
\hline III (poorly diff) & 70 & 46.36 \\
\hline PET $^{\ddagger}$ SUVmax $>10$ & 66 & 43.71 \\
\hline PET SUVmax $<10$ & 85 & 56.29 \\
\hline PET LNs positive & 47 & 31.13 \\
\hline PET LNs negative & 104 & 68.87 \\
\hline EUS ${ }^{\S}$ length $>3 \mathrm{~cm}$ & 67 & 53.17 \\
\hline EUS length $<3 \mathrm{~cm}$ & 29 & 23.02 \\
\hline EUS LNs positive & 108 & 85.71 \\
\hline EUS LNs negative & 18 & 14.28 \\
\hline
\end{tabular}

${ }^{\dagger} \mathrm{M}$ : male, F: female

'PET: positron emission tomography

${ }^{\S}$ EUS: endoscopic ultrasound

during the study period (2008-2012 30.36\% vs 2013-2014 53.65\%).

EUS had a higher sensitivity (88.6\%) in assessing the status of the local lymph nodes but at the expense of a high false positive rate (80.85\%) and low specificity (19.15\%) as shown in Table 2. The accuracy of EUS overall was $62.7 \%$. Moreover, it has to be emphasized that EUS is not always feasible due to oesophageal lumen narrowing, and in this series it was performed in 126 patients out of 151 in total.

Kaplan Meier survival curves showing

Table 2. PET LNs and EUS LNs vs histopathological LNs status

\begin{tabular}{|c|c|c|c|c|c|c|}
\hline \multirow[b]{2}{*}{$\mathrm{PET}^{\dagger} \mathrm{LNS}^{\S}(+\mathrm{ve})$} & \multicolumn{2}{|c|}{$\begin{array}{c}\text { Sensitivity Percentages } \\
(\%)\end{array}$} & \multicolumn{2}{|c|}{$\begin{array}{c}\text { Specificity Percentages } \\
(\%)\end{array}$} & \multicolumn{2}{|c|}{$\begin{array}{c}\text { Accuracy Percentages } \\
(\%)\end{array}$} \\
\hline & $38 / 97$ & 39.2 & $45 / 54$ & 83.33 & $83 / 151$ & 54.97 \\
\hline EUS $^{\ddagger}$ LNs (+ve) & $70 / 79$ & 88.6 & $9 / 47$ & 19.15 & $79 / 126$ & 62.7 \\
\hline
\end{tabular}

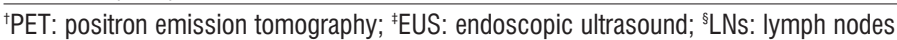




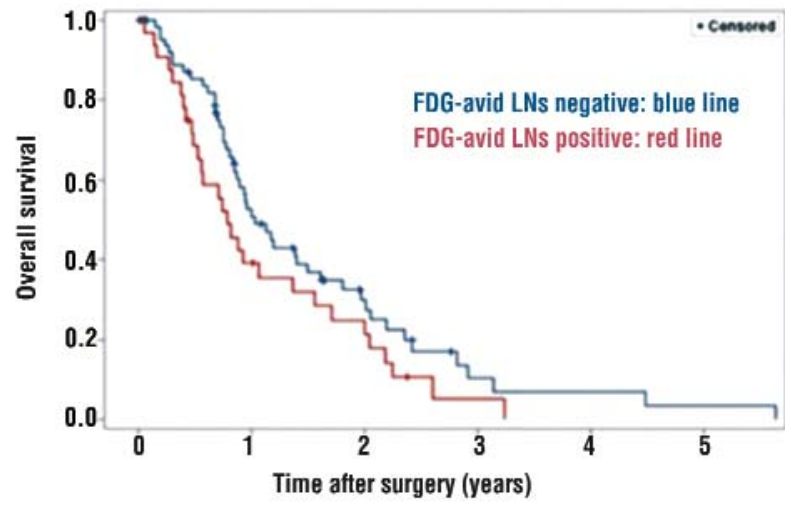

Figure 1. Kaplan-Meier survival plot overall according to PET/CT report of PET-avid local lymph nodes (positive vs negative) - Overall survival

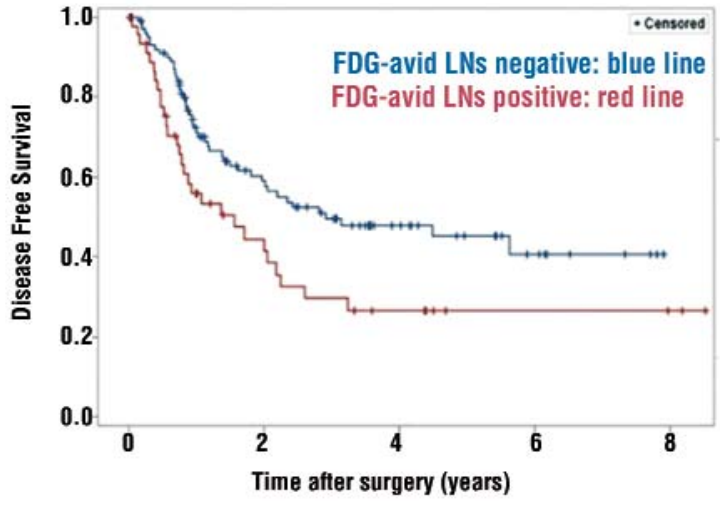

Figure 2. Kaplan-Meier survival plot overall according to PET/CT report of PET-avid local lymph nodes (positive vs negative) - Disease free survival survival and recurrence data according to PET FDG-avid LNs are presented in Fig. 1 and 2. No significant difference in survival was identified for patients with a high SUVmax (Overall survival $(\mathrm{OS}) \mathrm{p}=0.141$, disease free survival (DFS) $\mathrm{p}=0.527$ ). PET FDG-avid LNs (OS p=0.347, DFS $\mathrm{p}=0.107$ ), EUS LNs (OS $p=0.672$, DFS $p=0.065$ ), EUS tumour length (OS $\mathrm{p}=0.455$, DFS $\mathrm{p}=0.919$ ).

Univariate analysis results are summarized in Table 3. In the multivariate model, no statistically significant difference between the two groups was found for PET avid LN's (HR (95\% CI): OS 0.80(0.40-1.60), DFS 0.83 (0.381.79)) (Table 4). Likewise, EUS LNs positive (HR (95\% CI) OS: 2.79 (0.78-9.96), DFS:2.60 (0.63-10.70)),SUVmax of the primary tumour (>10) (HR (95\% CI) OS: $0.64 \quad(0.33-1.23)$, DFS:1.81 (0.80-4.08)) and EUS tumour

Table 3. Univariate (unadjusted) $\mathrm{HR}$ and $95 \% \mathrm{Cl}$ for overall survival and disease-free survival

\begin{tabular}{|c|c|c|}
\hline & $\begin{array}{l}\text { Overall death } \\
\text { HR (95\%CI) }\end{array}$ & $\begin{array}{l}\text { Recurrence } \\
\text { HR }(95 \% \mathrm{Cl})\end{array}$ \\
\hline $\mathrm{PET}^{+}-\mathrm{LNs}(+,-)$ & $1.24(0.79-1.94)$ & $1.46(0.92-2.33)$ \\
\hline EUS ${ }^{\ddagger}$ tumour length $(\mathrm{cm})$ & $1.00(0.91-1.11)$ & $0.98(0.89-1.09)$ \\
\hline EUS LNs $(+,-)$ & $1.16(0.58-2.35)$ & $2.01(0.94-4.29)$ \\
\hline $\operatorname{SUVmax}^{\S}(>10$ or $<10)$ & $0.73(0.48-1.11)$ & $0.86(0.54-1.37)$ \\
\hline Mandard score $(4,5$ vs $1,2,3)$ & $3.13(1.78-5.52)$ & $2.12(1.13-3.97)$ \\
\hline
\end{tabular}

length(HR (95\% CI) OS:1.02 (0.90-1.16), DFS:1.02 (0.86-1.21)) did not independently predict survival (Table 4). Interestingly, Mandard regression score of the primary tumour had good value prognostically on univariate [(HR and 95\% CI: OS 3.13 (1.78-5.52), DFS 2.12 (1.13-3.97)] and on the multivariate model [(HR and 95\% CI: OS2.17 (0.95-4.94), DFS 1.60 (0.61-4.23)], without though being independently significant.

Table 4. Multivariate $\mathrm{HR}$ and $95 \% \mathrm{Cl}$ for overall death and recurrence (adjusted for age, grade, stage, lympho vascular invasion, resection status, mandard score)

\begin{tabular}{|c|c|c|}
\hline & $\begin{array}{l}\text { Overall death } \\
\text { HR (95\%Cl) }\end{array}$ & $\begin{array}{l}\text { Recurrence } \\
\text { HR (95\%Cl) }\end{array}$ \\
\hline Age & $1.02(0.99-1.05)$ & $1.04(0.99-1.10)$ \\
\hline Grade (moderately vs poor) & $0.78(0.42-1.48)$ & $2.22(0.94-5.20)$ \\
\hline \multicolumn{3}{|l|}{ Stage } \\
\hline 1 & 1.00 (Ref) & 1.00 (Ref) \\
\hline 2 & $2.79(0.80-9.76)$ & $1.02(0.18-5.91)$ \\
\hline 3 & $9.23(1.60-53.27)$ & $2.38(0.29-19.93)$ \\
\hline Lymphovascular invasion & $0.47(0.12-1.83)$ & $0.75(0.15-3.82)$ \\
\hline Resection Satus & $1.25(0.60-2.63)$ & $1.38(0.61-3.09)$ \\
\hline Mandard score $(4,5$ vs $1,2,3)$ & $2.17(0.95-4.94)$ & $1.60(0.61-4.23)$ \\
\hline $\operatorname{SUVmax}^{\dagger}(>10$ or $<10)$ & $0.64(0.33-1.23)$ & $1.81(0.80-4.08)$ \\
\hline $\mathrm{PET}^{\ddagger}-\mathrm{LNS}^{\S}(+,-)$ & $0.80(0.40-1.60)$ & $0.83(0.38-1.79)$ \\
\hline EUST LNs $(+,-)$ & $2.79(0.78-9.96)$ & $2.60(0.63-10.70)$ \\
\hline EUS tumour length $(\mathrm{cm})$ & $1.02(0.90-1.16)$ & $1.02(0.86-1.21)$ \\
\hline
\end{tabular}

${ }^{\top}$ SUVmax: standardized uptake value-maximum; " ${ }^{\mathrm{PET}}$ : positron emission tomography; ' LNs: lymph nodes; đEUS: endoscopic ultrasound 


\section{Discussion}

This study has demonstrated that initial staging investigations for oesophageal adenocarcinoma have limitations and should be interpreted cautiously before finalising patient specific treatment plans. The accuracy of local lymph node assessment remains low but PET/CT and EUS may have complimentary roles in its prediction. Positive lymph nodes on PET/CT and EUS were not independently prognostic, in contrast to the findings of other studies (9-11).

Some methodological issues deserve attention. This was a large study in terms of patient numbers, compared to the existing literature, with patients drawn from a single centre's prospectively maintained database with mature follow-up. The study population was homogenous, focusing on adenocarcinoma patients being treated with curative intent. Nonetheless, it was not a prospective study, and despite adjustments for known confounders, may have been susceptible to bias.

Staging accuracy is known to be user dependent and although the current study's staging results are in line with, or better than, the existing literature, variations in individual interpretation and advances in imaging technology ensure this is a continually evolving field. Several factors may contribute to the reduced sensitivity of $\mathrm{PET} / \mathrm{CT}$ lymph node assessment. The 'partial volume effect', whereby local lymph nodes may be obscured by a metabolically active primary tumour, is known to influence the accuracy of PET/CT (12). As mentioned above in this study, accumulating experience of dedicated teams increases sensitivity. There are no published guidelines or radiological consensus on the metabolic criteria required to report a positive lymph node (4). It is also accepted that on histopathological examination a proportion of positive lymph nodes have micrometastases, without being enlarged (13). As shown finally, there may be a down-staging effect of neoadjuvant chemotherapy, and the studied investigations were performed prior to neoadjuvant treatment. As a result of these factors, there is increasing interest in the literature in post-neoadjuvant treatment PET/CT for prognosis and treatment response assessment (14-16). In principle, this would agree with work previously published by our group that tumour stage after neo-adjuvant chemotherapy is more important prognostically than staging performed at diagnosis (17).

Previous studies have attempted to assess the value of $\mathrm{PET} / \mathrm{CT}$ in predicting survival in oesophageal adenocarcinoma patients (9). One important study reported on a cohort of 121 patients, concluding that FDG-avid local lymph nodes adversely influenced disease-free and overall survival, while SUVmax and tumour length did not (9). Interestingly this prognostic role for PET/CT avid lymph nodes was also present in the context of poor overall sensitivity for pathologically confirmed lymph nodes, suggesting that high metabolic activity in local lymph nodes may be a surrogate for more advanced disease or adverse tumour biology.

This study's data also suggest that high SUVmax on PET/CT and increased tumour length on EUS do not correlate with recurrence or survival. The latter is consistent with several studies $(9,18)$, and contradicts others $(19,20)$. It has to be emphasized that these studies were small and included both adenocarcinoma and squamous cell carcinoma patients, without distinguishing between those patients having neoadjuvant treatment and primary surgery.

Most patients with oesophageal cancer being considered for resection present with locally advanced disease and, as a result, are considered for peri-operative chemotherapy. Specific lymph node status, whilst important for prognosis, seldom changes the management of these patients. However, certain scenarios do require accurate lymph node prediction. The management of early tumours with endoscopic mucosal resection mandates an accurate assessment of local lymph nodes to avoid under-treating disease, particularly as the indications for endoscopic therapy expand to include tumours with early submucosal extension (T1b) (21). Likewise, 
primary surgery would not be normally considered in patients staged as lymph node positive. Additionally, with the recognition that multi-node positive patients have a high likelihood of systemic disease, the role of surgery is increasingly being questioned for this poor prognosis group. In all of the above scenarios, lymph node status could significantly alter patient management and the conspicuous differences in the sensitivity of PET/CT and EUS inevitably lead to the debate of how we balance the risks of over and undertreatment of oesophageal cancer $(22,23)$.

Increasing experience with EUS and PET/CT have improved the accuracy of both modalities. The addition of fine needle aspiration (FNA) has also been shown to improve the sampling accuracy of EUS although conceivably at the risk of seeding the primary tumour (21). Adding new parameters such as EUS elastography or PET/MRI $(24,25)$, could potentially improve staging further. New molecular or metabolic techniques validated by high quality studies are undoubtedly needed to better assess tumour biology and response to chemotherapy.

\section{Conclusions}

In conclusion, this study has confirmed a low sensitivity for PET/CT and low specificity for EUS in the assessment of local LNs in oesophageal adenocarcinoma. These differences suggest the two modalities may be complimentary in local lymph node staging which remains one of the most important prognostic indicators in oesophageal cancer. PET/CT FDG-avid LNs, EUS lymph nodes, SUVmax of the primary tumour and EUS length did not independently predict prognosis in contrast to other studies in the literature. Post neo-adjuvant treatment imaging and staging modalities are important and need improvement in accuracy if we aspire to predict prognosis prior to surgery.

\section{Acknowledgements}

Additional authors for group acknowledgement:
Vicky Goh ${ }^{1,2}$, Nicholas Maisey ${ }^{3}$, Sarah Ngan ${ }^{3}$, Andrew Gaya ${ }^{3}$, Asad Qureshi ${ }^{3}$, Michael Green ${ }^{4}$, Fuju Chang ${ }^{4}$, Harriet Deere ${ }^{4}$, Baljit GillBarman $^{4}$, Simi George ${ }^{4}$, Jason Dunn ${ }^{5}$, Sebastien $Z^{2} \mathrm{eki}^{5}$, John Meenan ${ }^{5}$, Orla Hynes ${ }^{6}$, Christina Iezzi $^{7}$, Gemma Tham ${ }^{8}$

${ }^{1,2}$ Division of Imaging Sciences and Biomedical Engineering, Department of Cancer Imaging, Clinical PET Centre, St Thomas' Hospital, Kings College London, London, UK

${ }^{3}$ Dept. of Oncology, Guy's hospital, London

${ }^{4}$ Dept. of Histopathology, St. Thomas' hospital, London

${ }^{5}$ Dept. of Gatroenterology, St. Thomas' hospital, London

${ }^{6}$ Department of Dietetics, St. Thomas' hospital, London

${ }^{7}$ Department of Speech and Language Therapy, St. Thomas' hospital, London

${ }^{8}$ Department of Physiotherapy, St. Thomas' hospital, London.

\section{Conflict of Interest Statement}

All authors declare no conflict of interest regarding the publication of this article.

\section{References}

1. van Rossum PS, van Lier AL, Lips IM, et al. Imaging of oesophageal cancer with FDG-PET/CT and MRI. Clin Radiol. 2015;70(1):81-95.

2. Noble F, Bailey D, Tung K, Byrne JP. Impact of integrated PET/CT in the staging of oesophageal cancer: a UK population-based cohort study. Clin Radiol. 2009;64(7):699-705.

3. Kayani B, Zacharakis E, Ahmed K, Hanna GB. Lymph node metastases and prognosis in oesophageal carcinoma--a systematic review. Eur J Surg Oncol. 2011:37(9):747-753.

4. Devadas M, Mittal A, Lin M, et al. FDG-PET nodal staging does not correlate with histopathological nodal stage for oesophageal cancers. Int J Surg. 2015;20:113-117.

5. Foley KG, Lewis WG, Fielding P, et al. N-staging of oesophageal and junctional carcinoma: is there still a role for EUS in patients staged NO at PET/CT? Clin Radiol. 2014;69(9):959-964.

6. Cunningham D, Allum WH, Stenning SP, et al. Perioperative chemotherapy versus surgery alone for resectable gastroesophageal cancer. N Engl J Med. 2006;355(1):11-20.

7. Allum WH, Stenning SP, Bancewicz J, Clark PI, Langley RE. Longterm results of a randomized trial of surgery with or without preoperative chemotherapy in esophageal cancer. J Clin Oncol. 2009;27(30):5062-5067.

8. Chan DS, Reid TD, Howell I, Lewis WG. Systematic review and meta-analysis of the influence of circumferential resection margin involvement on survival in patients with operable oesophageal cancer. Br J Surg. 2013;100(4):456-464.

9. Gillies RS, Middleton MR, Han C, et al. Role of positron emission 
tomography-computed tomography in predicting survival after neoadjuvant chemotherapy and surgery for oesophageal adenocarcinoma. Br J Surg. 2012;99(2):239-245.

10. Fathinul Fikri AS, Dharmendran R, Vikneswaran P, Nordin AJ. 18FFDG PET/CT as a potential predictor of survival in patient with oesophageal cancer: a preliminary result. Abdom Imaging. 2015;40(6):1457-1464.

11. Valmasoni M, Pierobon ES, Ruol A, et al. Endoscopic Tumor Length Should Be Reincluded in the Esophageal Cancer Staging System: Analyses of 662 Consecutive Patients. PLoS One. 2016;11(4):e0153068

12. Hatt M, Le Pogam A, Visvikis D, Pradier O, Cheze Le Rest C. Impact of partial-volume effect correction on the predictive and prognostic value of baseline 18F-FDG PET images in esophageal cancer. J Nucl Med. 2012;53(1):12-20.

13. Bonavina L, Incarbone R, Midolo V, Bona D, Ferrero S, Dall'Asta C. (Prognostic significance of lymphatic micrometastasis of esophageal adenocarcinoma). Chir Ital. 2004;56(2):189-196.

14. Wang GM, Liu DF, Xu YP, Meng T, Zhu F. PET/CT imaging in diagnosing lymph node metastasis of esophageal carcinoma and its comparison with pathological findings. Eur Rev Med Pharmacol Sci. 2016;20(8):1495-1500.

15. Schmidt T, Lordick F, Herrmann K, Ott K. Value of functional imaging by PET in esophageal cancer. J Natl Compr Canc Netw. 2015;13(2):239-247.

16. Miyata $\mathrm{H}$, Yamasaki M, Makino $\mathrm{T}$, et al. Impact of number of ((18)F)fluorodeoxyglucose-PET-positive lymph nodes on survival of patients receiving neoadjuvant chemotherapy and surgery for oesophageal cancer. Br J Surg. 2016;103(1):97-104.

17. Davies AR, Gossage JA, Zylstra J, et al. Tumor stage after neo- adjuvant chemotherapy determines survival after surgery for adenocarcinoma of the esophagus and esophagogastric junction. J Clin Oncol. 2014;32(27):2983-2990.

18. Brown $\mathrm{C}$, Howes $\mathrm{B}$, Jamieson GG, et al. Accuracy of PET-CT in predicting survival in patients with esophageal cancer. World J Surg. 2012;36(5):1089-1095.

19. Kato $H$, Kuwano $H$, Nakajima $M$, et al. Comparison between positron emission tomography and computed tomography in the use of the assessment of esophageal carcinoma. Cancer. 2002;94(4):921-928.

20. van Westreenen HL, Plukker JT, Cobben DC, Verhoogt CJ, Groen H, Jager PL. Prognostic value of the standardized uptake value in esophageal cancer. AJR Am J Roentgenol. 2005;185(2):436-440.

21. DaVee T, Ajani JA, Lee JH. Is endoscopic ultrasound examination necessary in the management of esophageal cancer? World $\mathrm{J}$ Gastroenterol. 2017;23(5):751-762.

22. Cuellar SL, Carter BW, Macapinlac HA, et al. Clinical staging of patients with early esophageal adenocarcinoma: does FDG-PET/CT have a role? J Thorac Oncol. 2014;9(8):1202-1206.

23. Qumseya BJ, Brown J, Abraham M, et al. Diagnostic performance of EUS in predicting advanced cancer among patients with Barrett's esophagus and high-grade dysplasia/early adenocarcinoma: systematic review and meta-analysis. Gastrointest Endosc. 2015;81(4):865-874 e862.

24. Sazuka T, Akai T, Uesato M, et al. Assessment for diagnosis of lymph node metastasis in esophageal cancer using endoscopic ultrasound elastography. Esophagus. 2016;13:254-263.

25. Matthews R, Choi M. Clinical Utility of Positron Emission Tomography Magnetic Resonance Imaging (PET-MRI) in Gastrointestinal Cancers. Diagnostics (Basel). 2016;6(3). 